
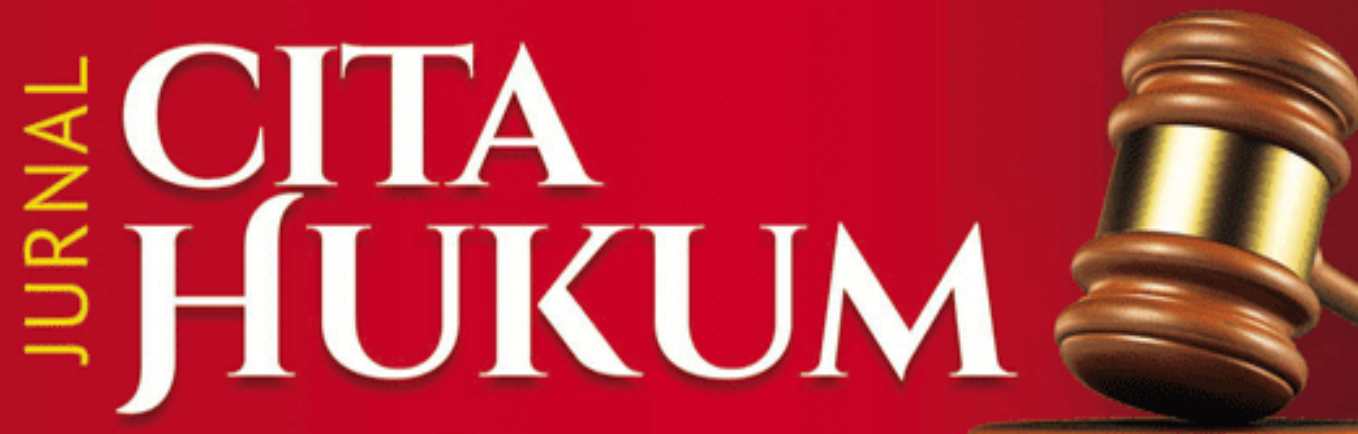

- Penerapan Hukum Jaminan Fidusia Dalam Kontrak Pembiayaan Syariah Muhammad Maksum

- Perlindungan Hukum Terhadap Tenaga Kerja Indonesia (Tinjauan Terhadap UU Nomor 39 Tahun 2004 Tentang Penempatan dan Perlindungan Tenaga Kerja Indonesia) Fatkhul Muin

- Kewenangan Legislasi Dewan Perwakilan Daerah Dalam Reformasi Kelembagaan Perwakilan Pasca Putusan Mahkamah Konstitusi Khamami Zada

- Konsep Pengakuan Bersalah Terdakwa Pada "Jalur Khusus" Menurut RUU KUHAP dan Perbandingannya Dengan Praktek Plea Bargaining Di Beberapa Negara Aby Maulana

- Scope of State Responsibility Against Terrorism in International Law Perspective; Indonesian Cases

Dian Purwaningrum Soemitro \& Indra Wahyu

- Pengendalian Sosial Kejahatan; Suatu Tinjauan Terhadap Masalah Penghukuman Dalam Perspektif Sosiologi Mas Ahmad Yani

- Perubahan Konstitusi dan Reformasi Ketatanegaraan Indonesia Abu Tamrin

- Konsep Perlindungan Hak Cipta Karya Musik Dalam Ranah Hukum Hak Kekayaan Intelektual Dari Tindak Pidana Pembajakan Oksidelfa Yanto 


\section{Jurnal}

\section{CITA HUKUM}

\section{VOL. 3 NO. 1 JUNI 2015}

Diterbitkan oleh Fakultas Syariah dan Hukum Universitas Islam Negeri (UIN) Syarif Hidayatullah Jakarta bekerjasama dengan Pusat Studi Konstitusi dan Legislasi Nasional (POSKO-LEGNAS) UIN

Jakarta. Jurnal Cita Hukum mengkhususkan diri dalam pengkajian Hukum Indonesia dan terbit dua kali dalam satu tahun di setiap bulan Juni dan Desember.

\section{Redaktur Ahli}

Muhammad Atho Mudzhar (UIN Syarif Hidayatullah Jakarta)

Muhammad Amin Suma (UIN Syarif Hidayatullah Jakarta)

Salman Maggalatung (UIN Syarif Hidayatullah Jakarta)

Ahmad Hidayat Buang (University Malaya Malaysia)

Nadirsyah Hosen (Wollongong University Australia)

JM Muslimin (UIN Syarif Hidayatullah Jakarta)

Stephen Koos (Munchen University Germany)

Abdullah Sulaiman (Universitas Trisakti)

Jimly Asshiddiqie (Universitas Indonesia)

Muhammad Munir (IIU Islamabad Pakisatan)

Tim Lindsey (Melbourne University Australia)

Raihanah Azahari (University Malaya Malaysia)

Jaih Mubarok (UIN Sunan Gunung Djati Bandung)

Djawahir Hejazziey (UIN Syarif Hidayatullah Jakarta)

\section{Editor in Chief}

Nur Rohim Yunus

Managing Editor

Muhammad Ishar Helmi

\section{Editors}

Fitria

Indra Rahmatullah

Mara Sutan Rambe

\section{Asisten to The Editors}

Erwin Hikmatiar

\section{Alamat Redaksi}

Fakultas Syariah dan Hukum UIN Syarif Hidayatullah Jakarta

Jl. Ir. H. Juanda 95 Ciputat Jakarta 15412

Telp. (62-21) 74711537, Faks. (62-21) 7491821

Website: www.fsh-uinjkt.net, E-mail: jurnal.citahukum@uinjkt.ac.id

Permalink: http://journal.uinjkt.ac.id/index.php/citahukum 


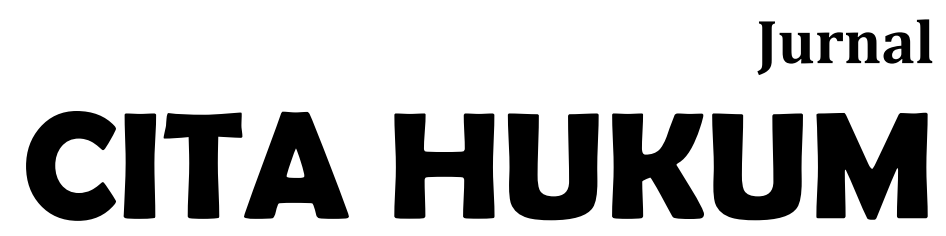

Menyambut baik kontribusi dari para ilmuwan, sarjana, profesional, dan peneliti dalam disiplin ilmu hukum untuk dipublikasi dan disebarluaskan setelah melalui mekanisme seleksi naskah, telaah mitra bebestari, dan proses penyuntingan yang ketat. 


\section{DAFTAR ISI}

1 Penerapan Hukum Jaminan Fidusia Dalam Kontrak Pembiayaan Syariah; Muhammad Maksum

11 Perlindungan Hukum Terhadap Tenaga Kerja Indonesia (Tinjauan Terhadap UU Nomor 39 Tahun 2004 Tentang Penempatan dan Perlindungan Tenaga Kerja Indonesia)

\section{Fathul Muin}

25 Kewenangan Legislasi Dewan Perwakilan Daerah dalam Reformasi Kelembagaan Perwakilan Pasca Putusan Mahkamah Konstitusi Khamami Zada

39 Konsep Pengakuan Bersalah Terdakwa Pada “Jalur Khusus” Menurut RUU KUHAP dan Perbandingannya Dengan Praktek Plea Bargaining di Beberapa Negara

Aby Maulana

67 Scope of State Responsibility Against Terrorism In International Law Perspective; Indonesian Cases

Dian Purwaningrum Soemitro \& Indra Wahyu Pratama

77 Pengendalian Sosial Kejahatan (Suatu Tinjauan Terhadap Masalah Penghukuman Dalam Perspektif Sosiologi)

Mas Ahmad Yani

91 Perubahan Konstitusi dan Reformasi Ketatanegaraan Indonesia Abu Tamrin

99 Konsep Perlindungan Hak Cipta Karya Musik Dalam Ranah Hukum Hak Kekayaan Intelektual Dari Tindak Pidana Pembajakan Oksidelfa Yanto 
115 Tindak Pidana Korupsi (Dugaan Penyalahgunaan Wewenang) Pejabat Publik (Perspektif Undang-Undang Nomor 30 Tahun 2014 Tentang Administrasi Pemerintahan)

Fathudin

133 Perlindungan Hukum Bagi Investor Terhadap Praktik Kejahatan Insider Trading Pada Pasar Modal Di Indonesia

Fadilah Haidar

153 Penyalahgunaan Perjanjian Lisensi Merek Dalam Praktek Bisnis Hak Atas Kekayaan Intelektual Ida Rofida

169 Persamaan Unsur Pokok Pada Suatu Merek Terkenal (Analisis Putusan MA Nomor 162 k/pdt.sus-hki/2014)

Muhammad Dandi Pahusa 


\title{
Perlindungan Hukum Terhadap Tenaga Kerja Indonesia \\ (Tinjauan Terhadap UU Nomor 39 Tahun 2004 Tentang Penempatan dan Perlindungan Tenaga Kerja Indonesia)*
}

\author{
Fatkhul Muin \\ Fakultas Hukum Universitas Sultan Ageng Tirtayasa Serang \\ Jl. Raya Jakarta KM. 04, Kec. Serang Banten \\ Email: fatkhulmoen@gmail.com
}

\begin{abstract}
Legal Protection towards Indonesian Immigrant Workers): protection towards immigrant workers working abroad is one of state's obligations to its citizens. Act No 30 Year 2004 related to the Placement and Protection Immigrant Workers is enacted as mandated in Article $28 \mathrm{D}$ Indonesian Constitution whereas every citizen has the right to get a proper occupation. It means that every citizen has the right to work in abroad. Vice versae, it is state's responsibility to give protection towards Indonesian immigrants working abroad.
\end{abstract}

Key words: Placement, Protection, Indonesian Immigrants

\begin{abstract}
Abstrak: Perlindungan Hukum Terhadap Tenaga Kerja Indonesia di Luar Negeri (sebaiknya judul diganti: Perlindungan Hukum Terhadap Pekerja Imigran Asal Indonesia).Perlindungan terhadap tenaga kerja Indonesia yang bekerja di luar negeri merupakan bagian dari kewajiban negara untuk memenuhi hak-hak konstitusional sebagai warga negara. Undang-Undang Nomor 39 Tahun 2004 Tentang Penempatan dan Perlindungan Tenaga Kerja Indonesia sesuai dengan amanat UUD 1945 Pasal 28 D ayat 3, dimana setiap warga negera berhak untu mendapatkan pekerjaan yang layak. Artinya bahwa hak yang dimiliki setiap warga negera untuk bekerja di luar negeri diakui dan sebaliknya kewajiban negara untuk memberikan perlindungan terhadap tenaga kerja Indonesia yang bekerja di luar negeri.
\end{abstract}

Kata Kunci: Penempatan, Perlindungan, Tenaga Kerja Indonesia

DOI: $10.15408 /$ jch.v2i1.1838

*Naskah diterima: 25 Maret 2015, direvisi: 15 Mei 2015, disetujui untuk terbit: 10 Juni 2015. 


\section{Fatkhul Muin}

\section{Pendahuluan}

Indonesia secara formil sejak tahun 1945 (UUD pra amandemen) telah mendeklarasikan diri sebagai negara hukum dan dipertegas lagi dalam UndangUndang Dasar Republik Indonesia 1945 (selanjutnya disebut dengan UUD RI 1945) hasil amandemen dalam pasal 1 ayat 3 yang menetapkan: "Negara Indonesia dalah negara hukum". Sehingga, dengan memperhatikan rumusan konsep negara hukum Indonesia, Ismail Suny mencatat empat syarat negara hukum secara formil yang menjadi kewajiban Pemerintah untuk dilaksanakan, Yaitu, Hak Asasi Manusia, Pembagian Kekuasaan, Pemerintahan berdasarkan Undang-Undang dan Peradilan Administrasi. ${ }^{1}$ sebagai negara hukum, maka setiap masyarakat memiliki kedudukan yang sama satu dengan yang lainnya tanpa adanya perbedaan (equlity before the law).

Perlindungan terhadap buruh/pekerja merupakan bagian yang tidak dapat terpisahkan dari perlindungan terhadap warga negara sebagai kewajiban negara. Hak-hak dasar sebagai manusia harus terpenuhi dengan mendapatkan perlindungan dimana saaja mereka berkerja untuk mendapatkan hak-hak dasarnya. Baik berbeda status warga negaranya maupun sama status werga negaranya, sehingga mereka mendapatkan kehidupan yang layak sebagai sesorang manusia sesuai dengan Pasal 28 D Ayat 3 UUD NRI 1945, bahwa: "Setiap warga negara memiliki Hak untuk bekerja dan mendapat imbalan serta perlakuan yang adil dan layak dalam hubungan kerja."

Dalam hubungan buruh/pekerja dan pengusaha berlaku hukum otonomi dan hetronomi, dan adanya hukum otonomi dan hetronomi inilah yang melahirkan hukum perburuhan bersifat hukum privat dan hukum publik. Bersifat hukum privat artinya hukum perburuhan mengatur hubungan antara buruh dengan pengusaha di mana masing-masing pihak bebas untuk menentukan bentuk dan isi hubungan kerja diantara mereka. Bersifat hukum publik menunjukan pada adanya peraturan hukum yang bersifat memaksa yang harus ditaati oleh pengusaha dan buruh apabila mereka melakukan hubungan sebelum, selama, dan sesudah masa kerja. ${ }^{2}$

Penempatan tenaga kerja Indonesia di luar negari merupakan upaya pemerintah untuk mengurangi tingkat pengangguran di Indonesia yang besar. Dalam data Badan Pusat Statistik (BPS) menyatakan tingkat pengangguran terbuka di Indonesia pada Februari 2012 mencapai 6,32\% atau 7,61 juta orang. Dengan tingginya tingkat pengangguran terbuka di Indonesia, maka diperlukan adanya solusi untuk menyelesaikan permasalahan-permasalahan yang terjadi akibat dari tingkat pengangguran yang tinggi. Salah satu solusi yang cepat dilakukan oleh masyarakat adalah dengan bekerja sebagai tenaga kerja Indonesia (TKI) di luar negeri. Sejalan dengan semua itu, pada hakikatnya sebagai upaya untuk mengurangi kemiskinan yang ada di Indonesia. Dalam data yang dirillis ole BNP2TKI, bahwa Indonesia menempatkan tenaga kerja Indonesia terbagi atas wilayah baik itu pada kerjaan formal ataupun informal, sebagai berikut :

1 Titik Triwulan Tutik, Pokok-pokok Hukum Tata Negara, (Jakarta: Prestasi Pustaka, 2006), h. 120.

2 Dede Agus, Hukum Ketenagakerjaan, (Serang :Dinas Pendidikan Provinsi Banten , 2012), h. 9-10. 
Tabel I.1

Penempatan Berdasar Daerah Asal (Kota/Kabupaten) (50 Besar Penempatan per Tahun Berdasar Daerah) Tahun 2011-2012

\begin{tabular}{|c|c|c|c|c|}
\hline No & Daerah Asal & 2011 & 2012 & Jumlah \\
\hline 1 & Indramayu & 30.545 & 10.047 & 40.592 \\
\hline 2 & Lombok Timur & 28.429 & $7.671 \|$ & 36.100 \\
\hline 3 & Cilacap & 22.360 & 8.062 & 30.422 \\
\hline 4 & Lombok Tengah & 23.374 & 5.190 & 28.564 \\
\hline 5 & Cirebon & 19.844 & 6.049 & 25.893 \\
\hline 6 & Cianjur & 18.958 & 3.536 & 22.494 \\
\hline 7 & Brebes & 13.808 & 5.223 & 19.031 \\
\hline 8 & Karawang & 15.003 & 3.280 & 18.283 \\
\hline 9 & Kendal & 14.020 & $4.237 \|$ & 18.257 \\
\hline 10 & Malang & 13.414 & 4.635 & 18.049 \\
\hline 11 & Sukabumi & 13.578 & 2.837 & 16.415 \\
\hline 12 & Ponorogo & 11.561 & 4.495 & 16.056 \\
\hline 13 & Blitar & 11.369 & 4.300 & 15.669 \\
\hline 14 & Subang & 12.274 & 3.361 & 15.635 \\
\hline 15 & Serang & 13.204 & 1.058 & 14.262 \\
\hline 16 & Banyuwangi & 9.932 & 3.568 & 13.500 \\
\hline 17 & Lombok Barat & 10.069 & 2.693 & 12.762 \\
\hline 18 & Banyumas & 8.075 & 2.827 & 10.902 \\
\hline 19 & Tulungagung & 9.282 & 1.243 & 10.525 \\
\hline 20 & Majalengka & 8.067 & 2.109 & 10.176 \\
\hline 21 & Pati & 7.141 & 2.686 & 9.827 \\
\hline 22 & Bandung & 7.766 & 1.638 & 9.404 \\
\hline 23 & Madiun & 6.739 & 2.484 & 9.223 \\
\hline 24 & Tegal & 6.035 & 3.025 & 9.060 \\
\hline 25 & Jakarta Utara & 6.094 & 2745 & 8.839 \\
\hline 26 & Lampung Timur & 6.491 & 2059 & 8.550 \\
\hline
\end{tabular}

Fakultas Syariah dan Hukum UIN Syarif Hidayatullah Jakarta - 13 


\begin{tabular}{|c|c|c|c|c|}
\hline 27 & Kediri & 6130 & 2350 & 8.480 \\
\hline 28 & Grobogan & 5.270 & 1.661 & 6.931 \\
\hline 29 & Bangkalan & 4.532 & 1.843 & 6.375 \\
\hline 30 & Sumbawa & 5.038 & 989 & 6.027 \\
\hline 31 & Purwakarta & 4.656 & 1.162 & 5.818 \\
\hline 32 & Magetan & 3.841 & 1.486 & 5.327 \\
\hline 33 & $\begin{array}{l}\text { Tangerang } \\
\text { (Kabupaten) }\end{array}$ & 4.481 & 781 & 5.262 \\
\hline 34 & Semarang & 3.799 & 1.457 & 5.256 \\
\hline 35 & Kebumen & 3.834 & 1.417 & 5.251 \\
\hline 36 & Jember & 3.942 & 1.146 & 5.088 \\
\hline 37 & Bekasi & 3.585 & 1.267 & 4.852 \\
\hline 38 & Trenggalek & 3.593 & 1.218 & 4.811 \\
\hline 39 & Kupang & 3.229 & 1.563 & 4.792 \\
\hline 40 & Lebak & 4.238 & 380 & 4.618 \\
\hline 41 & Medan & 3.188 & 1.385 & 4.573 \\
\hline 42 & Sragen & 3.476 & 1.072 & 4.548 \\
\hline 43 & Wonosobo & 3.376 & 1.172 & 4.548 \\
\hline 44 & Jakarta Timur & 3.230 & 1.207 & 4.437 \\
\hline 45 & Batang & 3.222 & 1.144 & 4.366 \\
\hline 46 & Demak & 3105 & 1.245 & 4.350 \\
\hline 47 & Ngawi & 2.962 & 1.111 & 4.073 \\
\hline 48 & Lampung Selatan & 3.089 & 875 & 3.964 \\
\hline 49 & Garut & 3.044 & 701 & 3.745 \\
\hline 50 & Banjarnegara & 2.650 & 908 & 3.558 \\
\hline 51 & Lain-Lain & 142.139 & 57.461 & 378.752 \\
\hline & Total & 581.081 & 188.059 & 948.292 \\
\hline
\end{tabular}

\section{Sumber : BNP2TKI}

Dalam ketentuan pasal 5 ayat (1 dan 2) Undang-Undang Nomor 39 Tahun 2004 Tentang Penempatan dan Perlindungan Tenaga Kerja Indonesia, bahwa Pemerintah bertugas mengatur, membina, melaksanakan, dan mengawasi penyelenggaraan penempatan dan perlindungan TKI di luar negeri dan Dalam melaksanakan tugas 
sebagaimana dimaksud pada ayat (1), Pemerintah dapat melimpahkan sebagian wewenangnya dan/atau tugas perbantuan kepada pemerintah daerah sesuai dengan peraturan perundang-undangan. Dari keseluruhan penempatan tenaga kerja Indonesia (TKI) yang ditempatkan di luar negeri, maka saudi arabis dan Malaysia merupakan salah satu negara yang menjadi tujuan warga negara Indonesia untuk mendapat pekerjaan. Ini terlihat dari tabel statistik dibawah ini.

Tabel I.2

Penempatan Per Tahun Per Negara (50 Besar Negara Penempatan)

\begin{tabular}{|c|c|c|c|c|c|c|}
\hline \multirow[t]{2}{*}{ No } & \multirow{2}{*}{$\begin{array}{c}\text { Negara } \\
\text { Penempatan }\end{array}$} & \multicolumn{4}{|c|}{ Tahun } & \multirow[t]{2}{*}{ Jumlah } \\
\hline & & 2009 & 2010 & 2011 & 2012 & \\
\hline 1 & Saudi Arabia & 276,633 & 228,890 & 137,643 & 11,814 & : $1,427,928$ \\
\hline 2 & Malaysia & 123,886 & 116,056 & 134,108 & 46,296 & $1,049,325$ \\
\hline 3 & Taiwan & 59,335 & 62,048 & 73,498 & 30,669 & 381,588 \\
\hline 4 & Singapore & 33,077 & 39,623 & 47,781 & 20,430 & 228,875 \\
\hline 5 & $\begin{array}{l}\text { United Emirate } \\
\text { Arab (Uea) }\end{array}$ & 40,391 & 37,337 & 39,857 & 14,274 & 220,820 \\
\hline 6 & Hong Kong & 32,417 & 33,262 & 50,283 & 18,237 & 214,476 \\
\hline 7 & Kuwait & 23,041 & 563 & 2,723 & 693 & 106,594 \\
\hline 8 & Qatar & 10,010 & 13,559 & 16,578 & 8,476 & 75,634 \\
\hline 9 & Yordania & 10,932 & 5,695 & 134 & 29 & 50,985 \\
\hline 10 & Oman & 9,700 & 9,259 & 7,292 & 3,375 & 50,295 \\
\hline 11 & Brunai Darussalam & 4,785 & 7,360 & 10805 & 5,703 & 46,848 \\
\hline 12 & Korea Selatan & 1,890 & 7,596 & 11,390 & 6,399 & 43,274 \\
\hline 13 & Amerika Serikat & 47 & 475 & 13,746 & 5,088 & 20,685 \\
\hline 14 & Bahrain & 2,837 & 4,844 & 4,375 & 2,832 & 20,118 \\
\hline 15 & Syria & 1,155 & 6,381 & 4222 & 1 & 11,759 \\
\hline 16 & Italia & - & 13 & 3,408 & 1,765 & 6,146 \\
\hline 17 & Jepang & 362 & 233 & 2,508 & 1,441 & 4,908 \\
\hline 18 & Aljazair & 453 & 609 & 1,084 & 563 & 3,208 \\
\hline 19 & Afrika Selatan & - & 12 & 2,009 & 786 & 2,918 \\
\hline 20 & Macao & 674 & 826 & 582 & 148 & 2,862 \\
\hline 21 & Spanyol & - & 10 & 1484 & 693 & 2,401 \\
\hline
\end{tabular}




\begin{tabular}{|c|c|c|c|c|c|c|}
\hline 22 & RRC & - & - & 1072 & 645 & 1,717 \\
\hline 23 & Thailand & 9 & 1 & 1113 & 426 & 1,549 \\
\hline 24 & Turki & - & 25 & 1016 & 352 & 1,399 \\
\hline 25 & New Zealand & 269 & 279 & 468 & 212 & 1,299 \\
\hline 26 & Fiji & - & - & 556 & 447 & 1,003 \\
\hline 27 & Maldives & 20 & 80 & 638 & 185 & 945 \\
\hline 28 & Australia & - & 1 & 526 & 363 & 895 \\
\hline 29 & Nigeria & 81 & 9 & 588 & 88 & 848 \\
\hline 30 & Mauritius & - & 3 & 478 & 359 & 840 \\
\hline 31 & Brasil & - & 66 & 313 & 446 & 825 \\
\hline 32 & Belanda & - & 1 & 592 & 202 & 808 \\
\hline 33 & India & 2 & 12 & 519 & 236 & 769 \\
\hline 34 & Lain-lain & - & - & 17 & - & 714 \\
\hline 35 & Uruguay & - & - & 496 & 195 & 691 \\
\hline 36 & Cyprus & - & 37 & 356 & 295 & 689 \\
\hline 37 & Jerman & - & 1 & 299 & 354 & 667 \\
\hline 38 & Inggris & - & 6 & 491 & 119 & 624 \\
\hline 39 & Trinidad & - & - & 213 & 382 & 595 \\
\hline 40 & Papua New Guini & - & - & 309 & 239 & 548 \\
\hline 41 & Vietnam & - & - & 337 & 179 & 516 \\
\hline 42 & Libya & 35 & 251 & 83 & 3 & 486 \\
\hline 43 & Timor Leste & - & - & 425 & 35 & 463 \\
\hline 44 & Swiss & - & - & 174 & 277 & 451 \\
\hline 45 & Mesir & 2 & 13 & 265 & 130 & 410 \\
\hline 46 & Peru & - & - & 301 & 105 & 406 \\
\hline 47 & Portugal & - & 5 & 248 & 117 & 370 \\
\hline 48 & Yaman & 30 & 7 & 59 & 59 & 368 \\
\hline 49 & Rusia & - & 2 & 246 & 106 & 354 \\
\hline 50 & Perancis & - & 117 & 153 & 81 & 351 \\
\hline 51 & Lain-lain & 99 & 236 & 3,220 & 1,710 & 5,345 \\
\hline & Total & 632,172 & 575,803 & 581,081 & 188,059 & $3,998,592$ \\
\hline
\end{tabular}

Sumber : BNP2TKI

Tingginya jumlah tenaga kerja Indonesia yang bekerja di luar negeri terutama di Malaysia, menunjukan bahwa tingkat kemiskinan masyarakat Indonesia masih cukup tinggi, sehingga masyarakat Indonesia terutama yang berada pada ekonomi rendah memilih untuk mencari pekerjaan di luar negeri. pengiriman tenaga kerja Indonesia keluar negeri banyak menimbulkan masalah bagi tenaga kerja Indonesia, oleh karena 
itu keberadan sistem yang baik bagi prosedur pengiriman tenaga kerja Indonesia dapat melindungi tenaga kerja Indonesia yang berkerja di luar negeri dan tidak menimbulkan tindak pidana perdagangan orang.

\section{Perlindungan Hak-hak Konstitusional Warga Negara yang Bekerja di Luar Negeri Sebagai Negera Hukum.}

Negara hukum Indonesia yang menjadi landasan sebagai bagian dari usaha pemenuhan hak-hak konstitusional warganegara sesuai dengan Alinea Ke-IV Pembukaan Undang-Undang Dasar 1945, dimana menyatakan secara tersurat bahwa tujuan dari negara Indonesia adalah untuk menciptakan kesejahteraan masyarakat Indonesia. Konsep hubungan antara hukum nasional Indonesia yang berkaitan dengan penempatan dan perlindungan tenaga kerja Indonesia dengan hukum internasional melalui suatu konvensi atau perjanjian internasional melalui asas pacta sunt servanda dalam keterikatan pemerintah atas perjanjian internasional yang ditandatanganinya dalam teori ratifikasi atau pengesahan perjanjian internasional. John Locke menyebutkan bahwa manusia telah lahir dengan dilekati oleh hak-hak kodrat, hak-hak alamiah dan yang kemudian Ia sebut dengan hak-hak asasi. ${ }^{3}$ Selain dari konsep negara hukum yang berkembang di barat, di timur tengah pun berkembang konsep negara hukum dengan dasar negara madinah, dimana didasarkan kepada perjanjian yang dibuat oleh Nabi Muhammad SAW dengan penduduk madinah saat itu. Perjanjian tersebut menghasilkan konstitusi madinah sebagai undang-undang dasar negara madinah yang teruama mengatur kewajibankewajiban dan hak-hak warganegaranya. ${ }^{4}$

Maka untuk menjamin terlaksananya hak-hak asasi tersebut, manusia kemudian berkumpul dan menyetujui adanya perjanjian masyarakat untuk membentuk satu kelompok terpadu yang disebut masyarakat dan negara. Masyarakat kemudian menyerahkan sebagian hak-hak alamiahnya kepada masyarakat, menunjuk seorang penguasa, dan memberikan kewenangan untuk menjaga dan menjamin terlaksananya hak-hak asasi manusia. Namun, dalam menjalankan tugasnya ini, kekuasaan penguasa memiliki keterbatasan oleh hak-hak asasi tersebut, artinya dalam menjalankan kekuasaannya penguasa tidak boleh melanggar hak-hak asasi. Konsep negara hukum selanjutnya muncul sebagai pelengkap kekuasaan yang dimiliki oleh penguasa tersebut, sebagai dasar terhadap pemberian jaminan hukum dalam perlindungan hak-hak asasi manusia tiap anggota masyarakat. Menurut Ni'matul Huda dalam bukunya yang berjudul " Hukum Tata Negara Indonesia" menyebutkan bahwa ciri-ciri rechtsstaat adalah adanya Undang-Undang Dasar atau konstitusi yang memuat ketentuan tertulis tentang hubungan antara penguasa dan rakyat, adanya pembagian kekuasaan negara, serta diakui dan dilindunginya hak-hak kebebasan rakyat. Ciri-ciri tersebut menunjukkan bahwa ide sentral rechstaat adalah pengakuan

\footnotetext{
3 Soehino, Ilmu Negara, (Yogyakarta: Liberty, 2005), h.108.

${ }^{4}$ Muhammad Tahir Azhary, Negara Hukum (Suatu Studi Tentang Prinsip-Prinsipnya Dilihat dari Segi Hukum Islam, Impelentasinya pada Periode Negara Madinah dan Masa Kini), Jakarta : Kencan, 2008), h. 18.
} 


\section{Fatkhul Muin}

dan perlindungan terhadap hak-hak asasi manusia yang bertumpu pada prinsip kebebasan dan persamaan. ${ }^{5}$

Selain itu, Stahl juga menyebutkan rumusan konsep negara hukum (rechtstaat) antara lain: ${ }^{6}$ (a) Perlindungan hak-hak asasi manusia; (b) Pemisahan atau pembagian kekuasaan untuk menjamin hak-hak itu; (c) Pemerintahan berdasarkan peraturan perundang-undangan; dan (d) Peradilan administrasi dalam perselisihan.

Indonesia secara formil sejak tahun 1945 (UUD pra amandemen) telah mendeklarasikan diri sebagai negara hukum dan dipertegas lagi dalam UndangUndang Dasar Republik Indonesia 1945 (selanjutnya disebut dengan UUD RI 1945) hasil amandemen dalam pasal 1 ayat 3 yang menetapkan: "Negara Indonesia dalah negara hukum". Sehingga, dengan memperhatikan rumusan konsep negara hukum Indonesia, Ismail Suny mencatat empat syarat negara hukum secara formil yang menjadi kewajiban Pemerintah untuk dilaksanakan, Yaitu, Hak Asasi Manusia, Pembagian Kekuasaan, Pemerintahan berdasarkan Undang-Undang dan Peradilan Administrasi. ${ }^{7}$

Mengacu pada ketentuan konstitusi tersebut, pengakuan dan jaminan terhadap perlindungan hak asasi masyarakat Indonesia ditegaskan kembali dalam UUD RI 1945 Pasal 28. Pasal 28I ayat 4 menegaskan peranan Pemerintah dalam kaitannya dengan hak asasi manusia di Indonesia. Pasal tersebut menyebutkan bahwa "perlindungan, pemajuan, penegakan, dan pemenuhan hak asasi manusia adalah tanggung jawab negara terutama pemerintah". 8

Oleh karena itu, dalam rangka pemenuhan HAM, maka diperlukan adanya upaya pemerintah untuk memberikan perlindungan kepada setiap warga negara baik yang ada di dalam negeri atau yang ada di luar negeri terutama dalam bidang pekerjaan yang layak.

Pekerjaan mempunyai makna yang sangat penting dalam kehidupan manusia sehingga setiap orang membutuhkan pekerjaan. Pekerjaan dapat dimaknai sebagai sumber penghasilan seseorang untuk memenuhi kebutuhan hidup bagi dirinya dan keluarganya. Dapat juga dimaknai sebagai sarana untuk mengaktualisasikan diri sehingga seseorang merasa hidupnya menjadi lebih berharga baik bagi dirinya, keluarganya maupun lingkungannya. Oleh karena itu hak atas pekerjaan merupakan hak azasi yang melekat pada diri seseorang yang wajib dijunjung tinggi dan dihormati. ${ }^{9}$

Makna dan arti pentingnya pekerjaan bagi setiap orang tercermin dalam Undang-Undang Dasar Negara Republik Indonesia Tahun 1945 Pasal 27 ayat (2) menyatakan bahwa : "setiap Warga Negara Indonesia berhak atas pekerjaan dan penghidupan yang layak bagi kemanusiaan". Namun pada kenyataannya, keterbatasan akan lowongan kerja di dalam negeri menyebabkan banyaknya warga negara Indonesia/TKI mencari pekerjaan ke luar negeri. Dari tahun ke tahun jumlah mereka

\footnotetext{
${ }^{5}$ Ni'matul Huda, Hukum Tata Negara Indonesia, (Jakarta: RajaGrafindo Persada, 2005), h. 74.

${ }^{6}$ Ridwan HR., Hukum Administrasi Negara, (Jakarta: RajaGrafindo Persada, 2006), h. 3.

7 Titik Triwulan Tutik, Pokok-pokok Hukum Tata Negara, (Jakarta: Prestasi Pustaka, 2006), h. 120.

${ }^{8}$ Lihat Undang-Undang Dasar Republik Indonesia Tahun 1945, Pasal 28I ayat 4.

${ }^{9}$ Lihat penjelasan Undang-Undang No. 39 Tahun 2004 Tentang Penempatan dan Perlindungan
}

TKI. 
yang bekerja di luar negeri semakin meningkat. Besarnya animo tenaga kerja yang akan bekerja ke luar negeri dan besarnya jumlah TKI yang sedang bekerja di luar negeri di satu segi mempunyai sisi positif, yaitu mengatasi sebagian masalah penggangguran di dalam negeri namun mempunyai pula sisi negatif berupa resiko kemungkinan terjadinya perlakuan yang tidak manusiawi terhadap TKI. Resiko tersebut dapat dialami oleh TKI baik selama proses keberangkatan, selama bekerja di luar negeri maupun setelah pulang ke Indonesia. Dengan demikian perlu dilakukan pengaturan agar resiko perlakuan yang tidak manusiawi terhadap TKI sebagaimana disebutkan di atas dapat dihindari atau minimal dikurangi. ${ }^{10}$

Dalam setiap pekerjaan, maka adanya perjanjian yang dibuat oleh para pihak, dimana perjanjian tersebut merupakan suatu peristiwa dimana pihak yang satu berjanji kepada pihak yang lainnya untuk melakukan suatu hal, akibatnya pihak-pihak yang bersangkutan terikat oleh isi perjanjian yang mereka adakan. ${ }^{11}$ Sedangkan perjanjian kerja merupakan perjanjian yang dibuat antara buruh dengan majikan, dimana buruh menyatakan kesanggupannya untuk bekerja kepada majikan dengan menerima upah dan majikan menyatakan kesanggupannya untuk mempekerjakan buruh dengan membayar upah. ${ }^{12}$ secara umum, paling tidak isi perjanjian kerja memuat sebagai berikut : (a) Macam pekerjaan; (b) Lamanya perjanjian itu berlaku; (c) Besarnya upah uang sebulannya; (d) Lamanya waktu istirahat (cuti) dan besarnya upah selama cuti itu; (e) Jika ada, besarnya bagian dari keuntungan (tantieme) dan cara menghitung keuntungan; (f) Jika ada, cara pemberian pensiun atau bentuk pemberian untuk hari tua lainnya. (g) Bentuk upah lainnya; dan (h) Tempat dimana buruh itu harus dikembalikan atas biaya majikan. ${ }^{13}$

Selain itu, dalam ketentuan Pasal 55 dan 56 Undang-Undang No. 39 Tahun 2004 Tentang Penempatan dan Perlindungan TKI, dinyatakan bahwa Hubungan kerja antara Pengguna dan TKI terjadi setelah perjanjian kerja disepakati dan ditandatangani oleh para pihak. Setiap TKI wajib menandatangani perjanjian kerja sebelum TKI yang bersangkutan diberangkatkan ke luar negeri. Perjanjian kerja ditandatangani di hadapan pejabat instansi yang bertanggung jawab di bidang ketenagakerjaan dan dalam perjanjian kerja sekurang-kurangnya memuat : (a) Nama dan alamat Pengguna; (b) Nama dan alamat TKI; (c) Jabatan atau jenis pekerjaan TKI; (d) Hak dan kewajiban para pihak; (d) Kondisi dan syarat kerja yang meliputi jam kerja, upah dan tata cara pembayaran, hak cuti dan waktu istirahat, fasilitas dan jaminan sosial; dan (e) Jangka waktu perjanjian kerja.

Perjanjian kerja dibuat untuk jangka waktu paling lama 2 (dua) tahun dan dapat diperpanjang untuk jangka waktu paling lama 2 (dua) tahun. Tujuan dari adanya Undang-Undang Nomor 39 Tahun 2004 Tentang Perlindungan dan penempatan Tenaga Kerja Indonesia sebagai upaya pemerintah untuk melakukan perlindungan melalui

${ }^{10}$ Lihat penjelasan Undang-Undang No. 39 Tahun 2004 Tentang Penempatan dan Perlindungan

TKI.

11 Zainal Asikin, dkk, Dasar-Dasar Hukum Perburuhan, ( Jakarta : Raja Grafindo Persada, 2008), h.

36.

12 Zainal Asikin, dkk, Dasar-Dasar Hukum Perburuhan, ( Jakarta : Raja Grafindo Persada, 2008), h.

37.

${ }^{13}$ Imam Soepomo, Pengantar Hukum Perburuhan, (Jakarta : Djambatan, 2003), h. 72. 


\section{Fatkhul Muin}

regulasi didalam negeri dan melalui perjanjian yang bersifat $G$ to $G$ dalam bentuk perjanjian bilateral antar kedua negara.

\section{Asuransi Tenaga Kerja Indonesia Sebagai Jaminan Sosial Terhadap Tenaga Kerja Indonesia}

Asuransi secara terminologi memiliki pengertian pertanggungan atau perlindungan atas suatu objek dari ancaman bahaya yang menimbulkan kerugian. ${ }^{14}$ Ini menunjukan bahwa asuransi merupakan upaya untuk memberikan perlindungan yang diberikan oleh salah satu pihak kepada pihak lain. Menurut Jhon H Magee, dalam bukunya General Insurance yang dikutip oleh Abbas Salim, bahwa secara umum asuransi terbagi kedalam 2 bagian, yaitu Jaminan sosial dan asuransi sukarela (Voluntary Insurance). ${ }^{15}$ Jaminan sosial sebagai wujud dari asuransi wajib yang dilaksanakan oleh pemerintah, sehingga setiap warga negara wajib terdaftar sebagai asuransi sosial. Pada asuransi sukarela, pada hakikatnya merupaka asuransi komersial dan asuransi pemerintah. Asuransi komersial merupakan asuransi yang dikelola oleh pihak swasta dan asuransi pemerintah dikelola oleh pemerintah melalui BUMN. ${ }^{16}$

Tenaga kerja Indonesia yang berkerja tentu membutuhkan perogram asuransi sebagai upaya untuk melakukan perlindungan terhadap tenaga kerja Indonesia yang bekerja di luar negeri. berdasarkan pasal 63 ayat 1 UU No. 39 Tahun 2004 Tentang Penempatan dan Perlindungan Tenaga Kerja Indonesia, dinyatakan bahwa untuk mendapat Kartu Tanda Kerja Luar Negeri, maka sebagai salah satu syaratnya adalah tenaga kerja Indonesia harus ikut serta dalam program asuransi tenaga kerja Indonesia.

Berdasarkan ketentuan pasal 15 Permenakertrans No. 07/MEN/V/2010 Tentang Asuransi TKI, bahwa Premi asuransi TKI sebagaimana dimaksud pada ayat (1), ditetapkan sebesar Rp. 400.000,- (empat ratus ribu rupiah) yang terdiri dari: (1) Premi asuransi TKI pra penempatan sebesar Rp. 50.000,- (lima puluh ribu rupiah); (2) Premi asuransi TKI masa penempatan sebesar Rp. 300.000,- (tiga ratus ribu rupiah); dan (3) Premi asuransi TKI purna penempatan sebesar Rp. 50.000,- (lima puluh ribu rupiah).

Jenis program asuransi TKI meliputi: (1) Program asuransi TKI pra penempatan; (2) Program asuransi TKI selama penempatan;dan (3) Program asuransi TKI purna penempatan. Besarnya premi asuransi TKI sebagai berikut: (1) Perpanjangan perjanjian kerja untuk jangka waktu 1 (satu) tahun, sebesar $40 \%$ dari besarnya premi asuransi masa penempatan;dan (2) Perpanjangan perjanjian kerja untuk jangka waktu 2 (dua) tahun, sebesar $80 \%$ dari besarnya premi asuransi masa penempatan.

${ }^{14}$ Abdul Kadir Muhammad, Hukum Asuransi Indonesia, ( Bandung : PT. Citra Aditya Bakti, 2006), h. 5 .

${ }^{15}$ Abbas Salim, Asuransi dan Manajemen Resiko, (Jakarta : Raja Grafindo, 2007), h.. 2.

16 Berdasarkan pasal 14 ayat 1 dan 2 UU No. 2 tahun 1992 Usaha Perasuransian, bahwa asuransi sosial harus dikelola oleh Badan Usaha Milik Negara (BUMN).

20 - Jurnal Cita Hukum. Vol. 3 No. 1 Juni 2015. ISSN: 2356-1440. 
Dalam hal dilakukan perpanjangan perjanjian kerja, premi asuransi TKI purna penempatan tetap berlaku. Program asuransi TKI pra penempatan, meliputi: (1) Risiko meninggal dunia; (2) Risiko sakit dan cacat; (3) risiko kecelakaan; (4) Risiko gagal berangkat bukan karena kesalahan calon TKI;dan (5) Risiko tindak kekerasan fisik dan pemerkosaan/pelecehan seksual.

Program asuransi TKI selama penempatan, meliputi: (1) Risiko gagal ditempatkan bukan karena kesalahan TKI; (2) Risiko meninggal dunia; (3) Risiko sakit dan cacat; (4) Risiko kecelakaan di dalam dan di luar jam kerja; (5) Risiko Pemutusan Hubungan Kerja (PHK) secara perseorangan maupun massal sebelum berakhirnya perjanjian kerja; (6) Risiko upah tidak dibayar; (7) Risiko pemulangan TKI bermasalah; (8) Risiko menghadapi masalah hukum; (9) Risiko tindak kekerasan fisik dan pemerkosaan/pelecehan seksual; (10) Risiko hilangnya akal budi;dan (11) Risiko yang terjadi dalam hal TKI dipindahkan ke tempat kerja/tempat lain yang tidak sesuai dengan perjanjian penempatan.

Program asuransi TKI purna penempatan, meliputi: (1) Risiko kematian; (2) Risiko sakit; (3) risiko kecelakaan;dan (4) Risiko kerugian atas tindakan pihak lain selama perjalanan pulang ke daerah asal, seperti risiko tindak kekerasan fisik dan pemerkosaan/pelecehan seksual dan risiko kerugian harta benda.

Permenakertrans Nomor PER.07/MEN/V/2010 tentang Asuransi Tenaga Kerja Indonesia, dibatalkan Mahkamah Agung (MA). Setelah pembatalan oleh Mahkamah Agung, Kementrian Tenaga Kerja dan Transmigrasi mengeluarkan Kepmenakertrans yang terdiri dari : (a) Kepmenakertrans Nomor 212 tahun 2013 tentang penetapan Konsorsium Asuransi TKI "JASINDO" dengan Ketua PT. ASURANSI JASA INDONESIA (Persero) beserta anggotanya sebagai penyeleneggara program Asuransi TKI.; (b) Kepmenakertrans Nomor 213 tahun 2013 tentang penetapan Konsorsium Asuransi TKI "ASTINDO" dengan Ketua PT. ASURANSI ADIRA DINAMIKA; (c) Kepmenakertrans Nomor 214 tahun 2013 tentang penetapan Konsorsium Asuransi TKI MITRA TKI" dengan Ketua PT. ASURANSI SINAR MAS.

Keberadaan asuransi bagi tenaga kerja Indonesia memberikan dampak positif bagi perlindungan tenaga kerja Indonesia yang bersifat sistematis dan berbasis kepada sistem pengelolaan manajemen asuransi yang baik. Amanat UU No. 39 Tahun 2004 Tentang Penempatan dan Perlindungan TKI yang mengisyaratkan bahwa setiap tenaga kerja Indonesia harus memiliki asuransi, ini menunjukan bahwa sistem yang dibangun berdasarkan penanggulangan resiko.

\section{Tinjaun Perlindungan Hukum Terhadap Tenaga Kerja Indonesia di Malaysia}

Pada tahun 2006 di Bali, Indonesia menyepakati MoU (Memorandum of Understanding) dengan Malaysia terkait perlindungan pekerja rumah tangga. MoU ini secara spesifik mengatur perlindungan pekerja domestik Indonesia di Malaysia. Indonesia menghentikan sementara pengiriman PRT ke Malaysia pada 2009 menyusul sejumlah kasus penyiksaan terhadap TKI di sana. Setelah penghentian ini kedua pihak melakukan berbagai perundingan untuk memperbaiki aspek perlindungan pembantu rumah tangga. MoU sektor pekerja rumah tangga ditandatangani pada 2006 dan berakhir pada 13 Mei 2011, namun kedua negara 


\section{Fatkhul Muin}

sepakat melakukan perpanjangan MoU selama satu bulan. Pertemuan teknis Joint Working Group akan dilakukan oleh kedua negara setelah penandatangan MoU ini. Soal apakah kesepakatan baru ini akan mencabut moratorium atau penghentian sementara pembantu rumah tangga ke Malaysia, Suhartono menjawab: "Kita belum sampai ke sana yang penting ada kesepakatan perlindungan terhadap domestic worker di Malaysia". ${ }^{17}$

Perjanjian bilateral yang dibuat antara Pemerintah Indonesia dan Kerajaan Malaysia tentang perlindungan tenaga kerja Indonesia yang bersifat sementara, tentu akan mengakibatkan terjadinya kelalaian terhadap perlindungan. Akibat dari kurangnya perlindungan hukum, maka terjadi tingkat kekerasan terhadap pekerja Indonesia di luar negara. Berikut ini data statistik yang dikeluarka oleh migrant care :

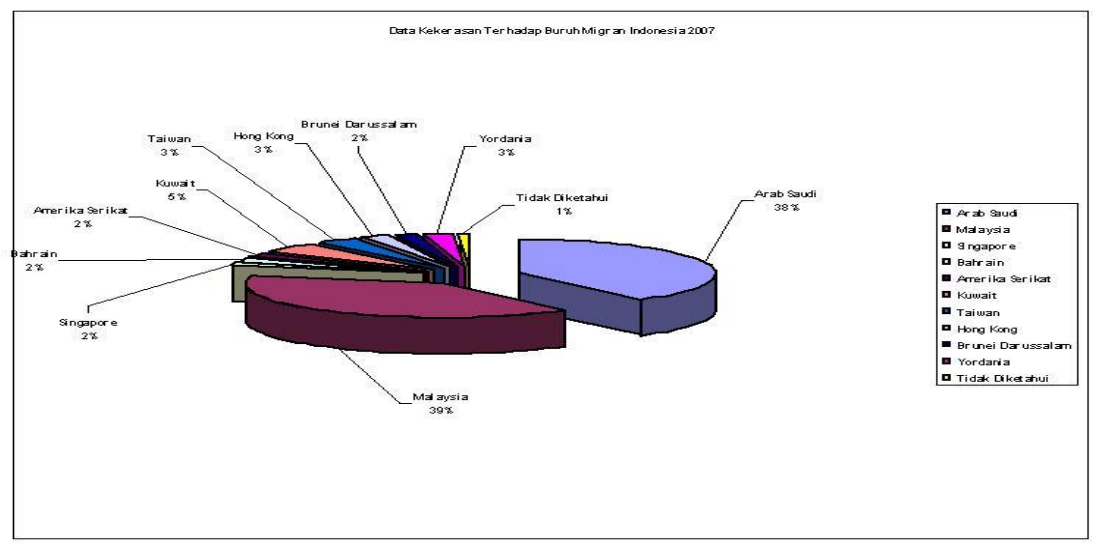

\section{Sumber : Migrant Care}

Malaysia merupakan negara yang menempati kasus tertinggi dalam kekerasan terhadap tenaga kerja Indonesia, bahkan mencapai 39\%. Tingginya tingkat kekerasan terhadap tenaga kerja Indonesia di Malaysia, tentu harus mendapatkan perhatian yang serius dari pemerintah Indonesia terhadap prosedur penempatan tenaga. Pada hakikatnya, sesuai dengan pasal 7 Undang-Undang 39 Tahun 2004 tentang Penempatan dan Perlindungan TKI, dimana pemerintah berkewajiban: (1) Menjamin terpenuhinya hak-hak calon TKI/TKI, baik yang berangkat melalui pelaksana penempatan TKI, maupun yang berangkat secara mandiri; (2) Mengawasi pelaksanaan penempatan calon TKI; (3) Membentuk dan mengembangkan sistem informasi penempatan calon TKI di luar negeri; (4) Melakukan upaya diplomatik untuk menjamin pemenuhan hak dan perlindungan TKI secara optimal di negara tujuan; dan (5) Memberikan perlindungan kepada TKI selama masa sebelum pemberangkatan, masa penempatan, dan masa purna penempatan.

${ }^{17}$ Tenaga kerja Malaysia, dalam

http://www.bbc.co.uk/indonesia/berita_indonesia/2011/05/110530_tkimalaysia.shtml. diunduh pada tanggal 01 Maret 2013. 
Kewajiban yang harus dilaksanakan oleh pemerintah merupakan bagian dari pemenuhan hak-hak dasar konstitusional warga negara yang bekerja di luar negeri. Pada sisi lain, tenaga kerja Indonesia mempunyai hak dan kewajiban sesuai dengan ketentuan Pasal 8 dan pasal 9, bahwa Setiap calon TKI/TKI mempunyai hak dan kesempatan yang sama untuk: (a) Bekerja di luar negeri; (b) Memperoleh informasi yang benar mengenai pasar kerja luar negeri dan prosedur penempatan TKI di luar negeri; (c) Memperoleh pelayanan dan perlakuan yang sama dalam penempatan di luar negeri;

(d) Memperoleh kebebasan menganut agama dan keyakinannya serta kesempatan untuk menjalankan ibadah sesuai dengan agama dan keyakinan yang dianutnya; (e) Memperoleh upah sesuai dengan standar upah yang berlaku di negara tujuan; (f) Memperoleh hak, kesempatan, dan perlakuan yang sama yang diperoleh tenaga kerja asing lainnya sesuai dengan peraturan perundang-undangan di negara tujuan; (g) Memperoleh jaminan perlindungan hukum sesuai dengan peraturan perundang-undangan atas tindakan yang dapat merendahkan harkat dan martabatnya serta pelanggaran atas hak-hak yang ditetapkan sesuai dengan peraturan perundang-undangan selama penempatan di luar negeri; (h) Memperoleh jaminan perlindungan keselamatan dan keamanan kepulangan TKI ke tempat asal; (i) Memperoleh naskah perjanjian kerja yang asli.

Setiap calon TKl/TKI mempunyai kewajiban untuk: (a) Mentaati peraturan perundang-undangan baik di dalam negeri maupun di negara tujuan; (b) Mentaati dan melaksanakan pekerjaannya sesuai dengan perjanjian kerja; (c) Membayar biaya pelayanan penempatan TKI di luar negeri sesuai dengan peraturan perundang-undangan; dan (d) Memberitahukan atau melaporkan kedatangan, keberadaan dan kepulangan TKI kepada Perwakilan Republik Indonesia di negara tujuan.

Hak dan kewajiban yang dilindungi oleh Undang-undang merupakan bagian dari upaya pemerintah untuk memberikan hak konstitusional warga negera. Keberadaan tenaga kerja Indonesia di Malaysia yang hanya didasarkan kepada perjanjian kerja yang selama ini ada antara tenaga kerja Indonesia dengan agency pengerah tenaga kerja Indonesia yang ada di Malaysia tentu tidak memberikan perlindungan terhadap tenaga kerja Indonesia yang berada di luar negeri, ini dapat terlihat dari banyaknya kasus-kasus yang terjadi sebagai akibat dari adanya ketidak jelasan perjanjian yang dibuat.

\section{Penutup}

Pengiriman tenaga kerja Indonesia keluar negeri merupakan upaya negara untuk memberikan jaminan perlindungan terhadap setiap warga negera untuk mencapatkan pekrjaan sesuai dengan amanat konstitusi baik di dalam negeri maupun di luar negeri. perlindungan terhadap tenaga kerja Indonesia yang bekerja di luar negeri melalui penempatan tenaga kerja Indonesia antara $G$ to $G$, atau melalui swasta maka membutuhkan perangkat untuk memberikan perlindungan terhadap tenaga kerja Indonesia. Keberadaan UU No. 39 Tahun 2004 Tentang Perlindungan dan Penempatan Tenaga Kerja Indonesia yang menjadi landasan yuridis tenaga kerja Indonesia yang bekerja di luar negeri sudah memberikan payung hukum bagi tenaga 


\section{Fatkhul Muin}

kerja Indonesia di luar negeri. salah satu upaya perlindungan yang diatur dalam ketentuan tersebut adalah prosedur keberangkatan TKI mulai dari informasi sampai dengan pemberangkatan. Asuransi tenaga kerja Indonesia merupakan bagian dari proteksi terhadap tenaga kerja Indonesia, tetapi pada aspek lain masih adanya permasalahan yang terjadi terutama berkaitan dengan teknis yaitu kalim asuransi tenaga kerja Indonesia, karena selama ini asuransi tenaga kerja Indonesia dikelola oleh swasta. Selain itu, peran serta perwakilan-perwakilan Indonesia di luar negeri diperlukan untuk melakukan pemantuan tenaga kerja Indonesia yang berada di luar negeri dan membantu menyelesaikan permasalahannya.

\section{Pustaka Acuan}

Agus, Dede, Hukum Ketenagakerjaan, Serang :Dinas Pendidikan Provinsi Banten, 2012.

Azhary, Muhammad Tahir, Negara Hukum (Suatu Studi Tentang Prinsip-Prinsipnya Dilihat dari Segi Hukum Islam, Impelentasinya pada Periode Negara Madinah dan Masa Kini), Jakarta : Kencana, 2008.

Asikin, Zainal , dkk, Dasar-Dasar Hukum Perburuhan, Jakarta : Raja Grafindo Persada, 2008.

Fajar, Mukti FD dan Yulianto Achmad, Dualisme Penelitian Hukum Normatif dan Empiris, Jogjakarta: Pustaka Pelajar, 2010.

Huda, Ni'matul , Hukum Tata Negara Indonesia, Jakarta: RajaGrafindo Persada, 2005.

Muhammad, Abdul Kadir, Hukum Asuransi Indonesia, Bandung: PT. Citra Aditya Bakti, 2006.

Salim, Abbas , Asuransi dan Manajemen Resiko, Jakarta : Raja Grafindo, 2007.

Soepomo, Imam, Pengantar Hukum Perburuhan, Jakarta : Djambatan, 2003.

Soehino, Ilmu Negara, Yogyakarta: Liberty, 2005.

Tutik, Titik Triwulan, Pokok-pokok Hukum Tata Negara, Jakarta: Prestasi Pustaka, 2006.

Ridwan HR., Hukum Administrasi Negara, Jakarta: RajaGrafindo Persada, 2006.

\section{Undang-Undang :}

Undang-Undang Dasar NRI 1945

Undang-Undang No. 39 Tahun 2004 Tentang Penempatan dan Perlindungan TKI. 
